\title{
Research and Practice on the Cultivation of Engineering Competence for Software Talents in Universities
}

\author{
Xiyu Pang \\ Shan Dong Jiaotong University, Jinan, China \\ Email: wangcheng 1001@163.com \\ Received 27 January 2015; accepted 15 February 2015; published 16 February 2015 \\ Copyright (C) 2015 by author and Scientific Research Publishing Inc. \\ This work is licensed under the Creative Commons Attribution International License (CC BY). \\ http://creativecommons.org/licenses/by/4.0/

(c) (i) Open Access

\begin{abstract}
This paper analyzes the phenomenon that companies are in need of talents, yet students have difficulty in finding jobs. It proposes new solutions for "Bridging the gap between university education and social demand and cultivating qualified talents for software companies", that is, to cultivate the students' competence for software engineering in curriculum design. Besides, it gives a scheme for cultivating the students' competence for software engineering in curriculum design, and delivers good results in practice.
\end{abstract}

\section{Keywords}

\section{Curriculum Design, Software Engineering Competence, “Three plus One” Training Model}

\section{Introduction}

With the globalization of economy and the arrival of information age, China attaches more and more importance to the information industry. In this background, IT companies see a booming development, which is in enlarging need of qualified IT talents. However, many IT companies have difficulty in finding the talents, and cannot carry out their projects. In the meanwhile, large amounts of college students are faced with tough job markets, and they are desperate in hunting for jobs. There is a cycle in the job market in IT industry: companies are in need of talents, yet students have difficulty in finding jobs [1] [2].

The reason behind this phenomenon is that fresh graduates lack experience in software development, most of which do not receive related training during their undergraduate study, nor do they have enough experience [3]. On the other hand, software companies are not obliged to put money and resources in training fresh graduates, and they tend to hire experienced IT talents. Therefore, it is an important issue to train the students into qualified 
talents for the market [4] [5].

Many domestic experts and scholars have conducted researches on how to cultivate the engineering capacity of computer major students. Reference [6] describes how to cultivate the high-quality applied talents of our school, but it only discusses the ability and quality which the university computer professional teacher should have; Reference [7] gives the scheme of software engineer talent cultivation that cultivates their basic quality, professional knowledge, learning ability, engineering consciousness, innovation ability, international exchange and cooperation, but it does not use the solution in practical teaching.

This paper analyses how to shorten the gap between school education and company needs in-depth, and on the basis, proposes the scheme that cultivates comprehensive software engineering qualities of students in curriculum design.

\section{Researches on the Training Plan of Software Talents}

Catering to the companies' need and cultivate qualified talents, most of the universities adopt "Three plus One" model, that is, the students receive education in the university for three years, and have one year training experience in software companies. After graduation, the students receive project practice in training institutions and go to work in software companies. This is the best training system for cultivating software talents, which is well received.

Before recruitment, what we could do consists of three phases, namely, curriculum setting and the define of teaching aims (including the choice of textbooks), giving lectures to achieve teaching aims, and curriculum design.

The first phase: curriculum setting, which is crucial for the cultivation of top talents for outsourcing to Japan. The setting of curriculum is the foundation for cultivation of "special" talents, and it determines the connotation of "special". Curriculum setting should meet the demand of the company to the maximum, and represent the main knowledge and technique for the development of mainstream software; it should lay a solid foundation for the cultivation of "special" talents, combining with the existing knowledge of college students. Otherwise, if the setting of the curriculum could not represent the connotation of cultivating "special" talents, it is impossible to achieve the final goal of lecture giving and curriculum design. In the first phase, we should choose the textbooks after setting the curriculum and the teaching aim. Since we have only a limited time for giving lectures in the university and for most of the time, the students study by themselves, therefore, it will be beneficial for the students to read an inspiring book. It would not achieve the expected teaching aim if we could not properly choose the textbook.

The second phase is lecture giving. From the point of view of training system, the aim of lecture giving is to achieve a certain subgoal of the general goal set in the first phase, and pave the road for the next phase of curriculum design. In order to cultivate well-received top talents, the teachers should fulfill the following three aspects:

1) Make the students understand and master the basic knowledge of the course.

2) Closely track the latest trend of mainstream software technology. For instance, the companies have already employed java 5.0 syntax, but we still teach java 1.2 syntax. We should illustrate and do practice on the mostly used knowledge in practical projects. We should conform to the technology that the companies are in need of.

3) Ask the students to write simple software programs as many as possible. The students could only understand the knowledge they learn by using them, and improve their project development skills.

It is not difficult to fulfill item 1) and 2), yet for item 3), it is not difficult to ask the students to write some simple independent programs not related with practice, however, the students would have difficulty in understanding how what they learn would be applied in practical program. Through curriculum design of java, we could make the students do some practical programs with the employment of JAVA.

The third phase is curriculum design, which is a practical teaching link. It refers to that after class the students do design practice, making use of their learned knowledge. The aim of curriculum design is: under the guidance of the teacher, by putting their knowledge into practical program writing, the students shall consolidate their basic knowledge, and have a new and thorough understanding of the problems they met in class; besides, the students shall understand the connection among their knowledge, and what they can do with their knowledge, what the social value their knowledge has, and it can stimulate their passion for learning; in addition, it can enhance the students' ability in developing practical programs, and integrate with the mainstream technology in software 
companies, and achieve the goal of cultivating top software talents.

As an instructor of curriculum design, I implement the integration of production, study and research in my teaching. Proceeding from the requirements of software companies, I make a close attention on the development trend of the mainstream technology in software companies. Besides, I keep on study and research, and form a rich teaching background. The detailed plan is as follows:

1) For the cultivation of the proficiency in Japanese (English): During my work in software companies, I realize that top software talents should not only have good technique, but also have proficiency in foreign language. We adopt the management model of software companies, and in the first 15 to 20 minutes of the first class we do morning report, during which the students give a speech or make a play in Japanese in turns; in the last 15 to 20 minutes of the class, the students should make a report (in Japanese or in English), in which he will report the schedule of his homework and the problems he met. We employ operating system and development tools in foreign language in software development environment in curriculum design. Stimulating the development environment in software companies, the abstract of curriculum is written in Japanese (or in English).

2) For the cultivation of coding skills and the awareness of coding standards: I give more detailed help for freshmen, enhance his awareness of the importance of tracing and debugging and standard coding; for sophomores and junior students, I stress on the cultivation of the skills in code optimization and algorithm optimization in the process of program design.

3) For the cultivation of the awareness of using software engineering concepts: for curriculum design in the first semester, we adopt the project development process and document writing requirements of software outsourcing companies in cooperation with our department. We strictly require the students to develop programs in accordance with practical development process, understand and master the concepts, methods, technique and writing norms of documents in the life cycles in software development (requirement analysis, outline design, detailed design, coding, unit testing, integration testing).

4) For the cultivation of teamwork: In curriculum design of the second semester for junior students, we transform some popular software or newly developed programs as curriculum design topic, divide the students into groups based on program management model of software companies, and the students accomplish a major curriculum design task together.

5) For the cultivation of hard-working spirit, self-directed learning ability, innovation ability and adaptability: For the choice of curriculum design subject, we should take the students' interest into consideration, and choose subject with moderate difficulty and moderate amount of subjects. Besides, we encourage the students to choose the subjects by themselves. We give stimulating help to students above the second grade, enhance their selfstudy ability and innovation ability, and make them master the mainstream technique and programming skills in practical project development; offer help to the students round the clock, exercise strict management for the students in curriculum design, attendance, sanitary of computer room and discipline, promote the students' occupational morality and responsibility; properly enlarge the task of curriculum design, in order to cultivate the students' hard-working spirit and their ability to cope with pressure. Effective code for each student in the three years should be no less than 12,000 lines.

\section{Conclusions}

The paper proposes the scheme that cultivates comprehensive software engineering qualities of students in curriculum design, and carried out the scheme in the computer science and technology major of Shan Dong Jiaotong University.

Results show that these measures have brought tangible effect. As the Shandong provincial demonstration base for personnel training of Japan-oriented software outsourcing talents, our department is among the first in the cultivation of Japan-oriented software outsourcing talents in universities in Shandong. We have 1600 fulltime undergraduates for software outsourcing to Japan up to now. 30\% of the employees in Japan-oriented software outsourcing companies graduate from our department, and they are well received.

\section{Acknowledgements}

Shandong Province Soft Science Research Project (No. 2014RKB01930); Jinan Technology Development Soft Science Research Project (No. 201221160); Shan Dong Jiaotong University Teaching Research Project (No. JY201308). 


\section{References}

[1] Lao, S.Y., Jiang, X.P. and Lao, M.R. (2013) The Effect of Mooc on IT after the Era of Higher Education. Journal of Higher Education Research, 3.

[2] Wang, W.L. (2013) The Development of MOOC and Its Effects on Higher Education. Jiangsu Higher Education, 2.

[3] Meng, X.F. and Ci, X. (2013) Large Data Management: Concepts, Technologies and Challenges. Research and Development of Computer, 1.

[4] (2010) The Reform and Practice on Communication Electronic Circuit Course. 2010 International Conference on EHealth Networking, Digital Ecosystems and Technologies Proceedings, 2.

[5] (2010) The Research of Software Engineering Curriculum Reform. Proceedings of 2010 3rd International Conference on Education Technology and Training, 3.

[6] Chu, M. (2008) Research and Development of High-Tech Industry in Our Country IT Knowledge Employee Ability. Tianjin University, Tianjin.

[7] Cui, W., Zhang, J. and Xing, G.B. (2011) Pattern of Talents Training in Software Engineering for Employment. Chinese Adult Education, 14. 
Scientific Research Publishing (SCIRP) is one of the largest Open Access journal publishers. It is currently publishing more than 200 open access, online, peer-reviewed journals covering a wide range of academic disciplines. SCIRP serves the worldwide academic communities and contributes to the progress and application of science with its publication.

Other selected journals from SCIRP are listed as below. Submit your manuscript to us via either submit@scirp.org or Online Submission Portal.
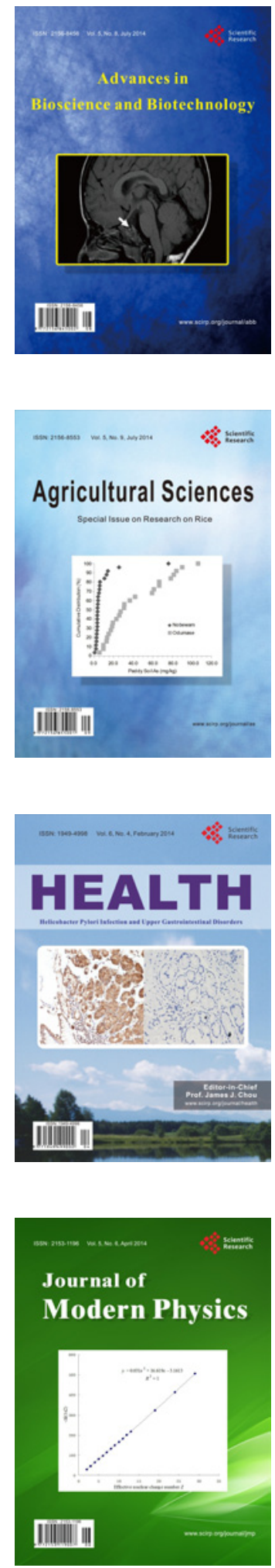
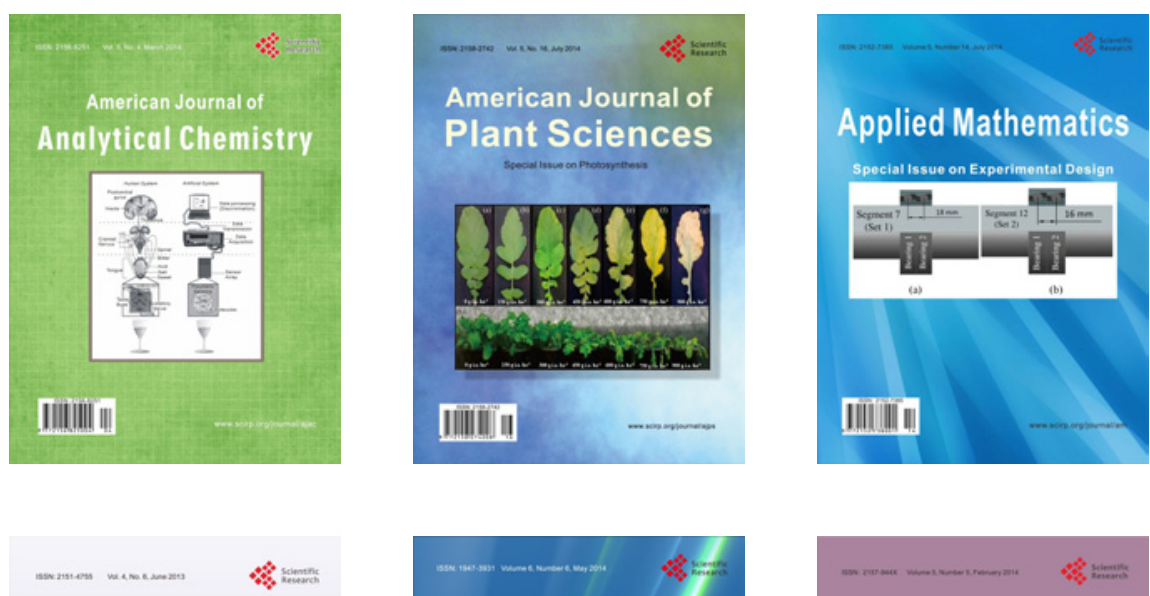

Creative Education
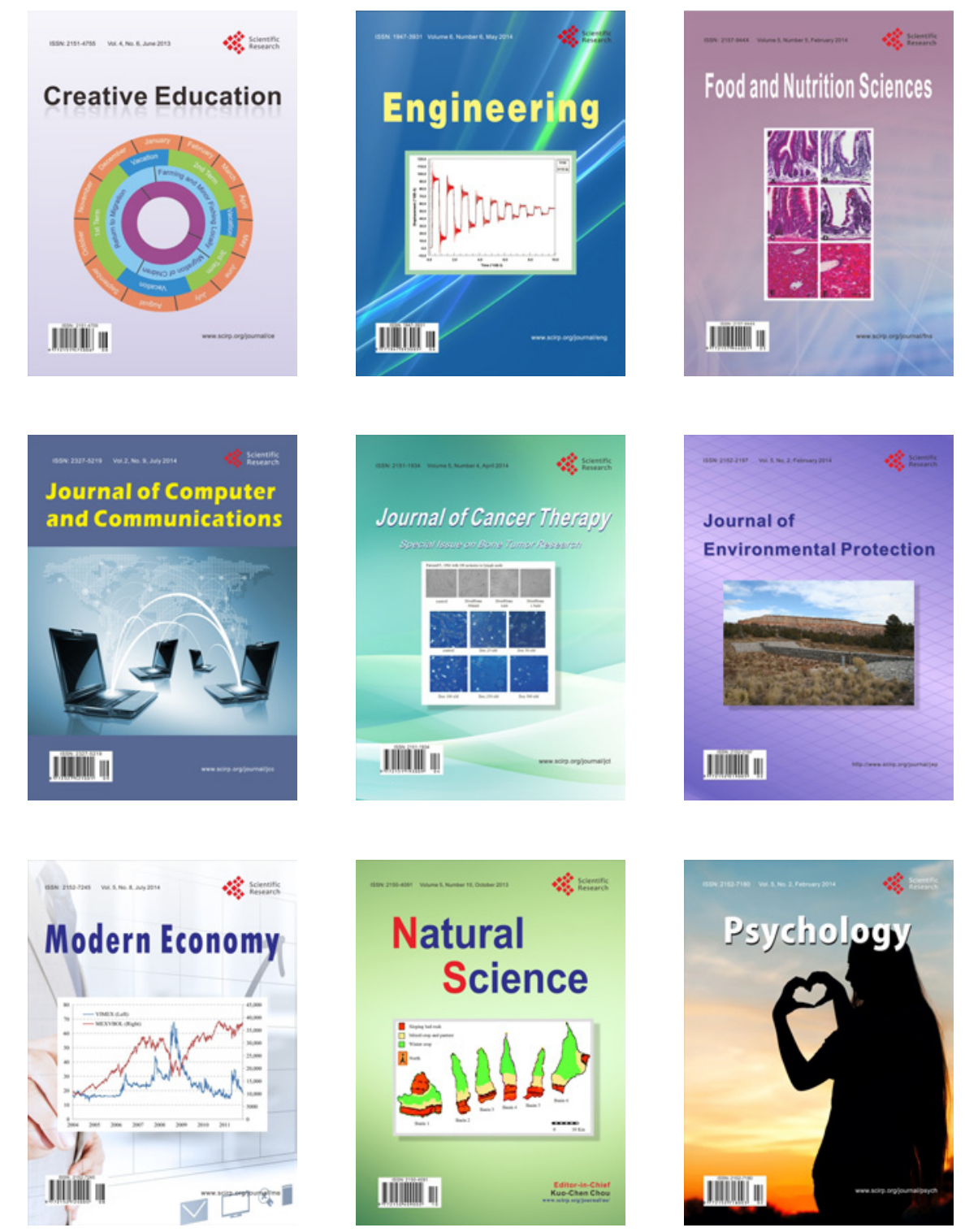